\title{
Derivation of water flooding characteristic curve for offshore low-amplitude structural reservoir with strong bottom water
}

\author{
Ying-xian Liu ${ }^{1} \cdot J_{i e} \operatorname{Tan}^{1}{ }^{1} \cdot$. Hui Cai ${ }^{1}$ Yan-lai Li ${ }^{1}$ Chun-yan Liu ${ }^{1}$
}

Received: 19 March 2021 / Accepted: 15 July 2021 / Published online: 21 July 2021

(c) The Author(s) 2021

\begin{abstract}
The water flooding characteristic curve method is one of the essential techniques to predict recoverable reserves. However, the recoverable reserves indicated by the existing water flooding characteristic curves of low-amplitude reservoirs with strong bottom water increase gradually, and the current local recovery degree of some areas has exceeded the predicted recovery rate. The applicability of the existing water flooding characteristic curves in low-amplitude reservoirs with strong bottom water is lacking, which affects the accurate prediction of development performance. By analyzing the derivation process of the conventional water flooding characteristic curve method, this manuscript finds out the reasons for the poor applicability of the existing water flooding characteristic curve in low-amplitude reservoir with strong bottom water and corrects the existing water flooding characteristic curve according to the actual situation of the oilfield and obtains the improvement method of water flooding characteristic curve in low-amplitude reservoir with strong bottom water. After correction, the correlation coefficient between $\frac{k_{r o}}{k_{r w}}$ and $S_{w}$ is $95.92 \%$. According to the comparison between the actual data and the calculated data, in $2021 / 3$, the actual water cut is $97.29 \%$, the water cut predicted by the formula is $97.27 \%$, the actual cumulative oil production is $31.19 \times 10^{4} \mathrm{t}$, and the predicted cumulative oil production is $31.31 \times 10^{4} \mathrm{t}$. The predicted value is consistent with the actual value. It provides a more reliable method for predicting low-amplitude reservoirs' recoverable ability with strong bottom water and guides the oilfield's subsequent decision-making.
\end{abstract}

Keywords Strong bottom water reservoir $\cdot$ Low-amplitude structure $\cdot$ Water flooding characteristic curve $\cdot$ Recoverable reserves

\section{Preface}

When the water flooding characteristic curve was first put forward, a statistical relationship appeared for its production data and had no theoretical significance. In 1959, the field data were first used to obtain the water flooding characteristic curve's statistical law, from which the water flooding characteristic curve can be used as an intuitive and straightforward statistical expression of dynamic reservoir law. At present, the water flooding characteristic curve method has been widely valued and applied (Muskat et al. 1935, Abass et al. 1988, Guo et al. 1992, Yuanqian 1994). The water flooding characteristic curve method can predict the water

Jie Tan

4687610@qq.com

1 Bohai Petroleum Research Institute, Tianjin Branch of CNOOC Ltd, Tianjin, China flooding oilfield's related development indexes and effectively predict and judge the water flooding oilfield's movable reserves and original geological reserves.

Because different types of oilfields have their characteristics, the realization of production performance of different types of oilfields would be inconsistent. Therefore, different types of oil fields would have the corresponding water flooding characteristic curve. Different reservoir types, reservoir physical properties, and crude oil properties show different dynamic characteristics. Based on statistical research, some scholars put forward various expressions of the water flooding characteristic curve. It reflects the particularity of oilfield production performance (Cunyou et al. 2011, Liu 2020, Recham 2000). Because of this particularity, some different expressions may be proposed in future. As long as several oilfield examples prove, it is the enrichment and enrichment of the research content. As a hot topic, many scholars are actively engaged in this research and exploration and have made many achievements, which is scientific progress. 
Many scholars in the former Soviet Union have proposed various water flooding characteristic curves (Olabode et al. 2021; Hanqiao et al. 2006; Qitai 1998). At present, the widely used water flooding characteristic curves are Сазонов Б.Ф., Сипачев Н.В., and Назаров С. Н.. In 1978, Tong Xianzhang studied the water flooding characteristic curve expressed by the relationship between the logarithm of cumulative water production and cumulative oil production and established a complete application system. He began applying and researching the water flooding characteristic curve (Jackson et al. 2005; Wenjun et al. 2000; Qitai 1999). Chen Yuanqian combined with the Nonpiston theory of water flooding and made theoretical verification оn Максимов М. И. water flooding characteristic curve, Сазонов Б.Ф. water flooding characteristic curve, and Сипачев Н.В. water flooding characteristic curve. The new water flooding characteristic curves proposed in the following research literature have been theoretically deduced or verified. With the deepening of application and research, it is found that different water flooding characteristic curves reflect different oil-water two-phase seepage characteristics.

The derivation of the water flooding characteristic curve is based on the semi-logarithmic linear relationship between the ratio of oil to water relative permeability and water saturation (Wenjun and Jun 2007; Yuanqian 1993; Jian et al. 2013; Chuanliang 2005). The relationship between oil and water relative permeability and water saturation only conforms to the linear relationship in the middle part but deviates from the linear relationship in the early development and ultra-high water cut stages. Therefore, the water flooding characteristic curve is generally applicable to the two parameters (water/oil ratio, cumulative oil production, oil recovery) in the rectangular coordinate system after the water cut reaches $40 \%$ cumulative water production. When there is a linear relationship or semi-logarithmic linear relationship, in the reservoir with strong bottom water and low amplitude, the water cut rises very fast, there is no water-free oil recovery period, and it would soon enter the high water cut period. When the oilfield enters the ultra-high water cut stage, the relationship between the ratio of oil and water relative permeability and water saturation deviated from the straight line, and the conventional water flooding characteristic curve would also deviate from the straight line. Simultaneously, applying the conventional water flooding characteristic curve to predict the development index would produce a significant error (Qi-tai 1999; Shaoxian.2012; Hua et al. 2013; Changfu et al. 2011). In this study, a new expression of the relationship between oil-water relative permeability and water saturation is proposed, and a water flooding characteristic curve suitable for low-amplitude reservoirs with strong bottom water is established. On this basis, a new type of water flooding characteristic curve is derived. Through the verification analysis, the new water flooding characteristic curve can reasonably predict the development index of the reservoir with strong bottom water and low amplitude, which is more in line with the actual reservoir development.

\section{Deflection of conventional water flooding characteristic curve method in high water cut stage}

In this study, the conventional water flooding characteristic curve (Table 1) predicts the oil recovery in the reservoir's medium and high water cut period with strong bottom water and low amplitude. It is found that there is a big gap with the actual situation, so it is not applicable.

The conventional water flooding characteristic curve method considers that the relative permeability ratio of oil-water two-phase is expressed as $\frac{k_{r o}}{k_{r w}}=c e^{-d \cdot S_{w}}$. Through actual data discovery, the relationship between $\ln \left(\frac{k_{r o}}{k_{r w}}\right)$ and $S_{w}$ is only linear for some time (Shuhong et al. 2011; Qiaoyun et al. 2011; Yuanqian and Dang 2004; Welge 1952; Goda et al. 2007; Wang et al. 2013). There is a downward tilt in the later period (see Fig. 1). During the derivation of the conventional water flooding characteristic curve method $\overline{S_{w}} \approx S_{w e}+\frac{1}{m f_{w}}$. It is assumed that after the oil field enters the high water cut stage $\left(f_{w}>80 \%\right)$, $\overline{S_{w}} \approx S_{w e}$. In other words, the water saturation at the high water cut the average saturation of formation can replace stage outlet. But in the actual reservoir, $\overline{S_{w}} \neq S_{w e}$. The formula $\frac{k_{r o}}{k_{r w}}=c e^{-d \cdot S_{w}}$ needs to be modified according to the actual oilfield.
Table 1 Ordinary water flooding characteristic curve

\begin{tabular}{ll}
\hline Types of water flooding characteristic curves & Expression \\
\hline Water flooding characteristic curve of Максимов М. И.-Xianzhang Т & $\log W_{p}=a+b N_{p}$ \\
Water flooding characteristic curve of Сазонов Б.Ф & $\log L_{p}=a+b N_{p}$ \\
Water flooding characteristic curve of Сипачев Н.В & $L_{p} / N_{p}=a+b L_{p}$ \\
Water flooding characteristic curve of Назаров С. Н & $L_{p} / N_{p}=a+b W_{p}$ \\
Water flooding characteristic curve of Jinqin Z & $W_{p} / N_{p}=-a+b W_{p} / N_{P}^{2}$ \\
Water flooding characteristic curve of Qitai Y & $\log N_{p}=a-b \log \left(L_{p} / W_{p}\right)$ \\
\hline
\end{tabular}




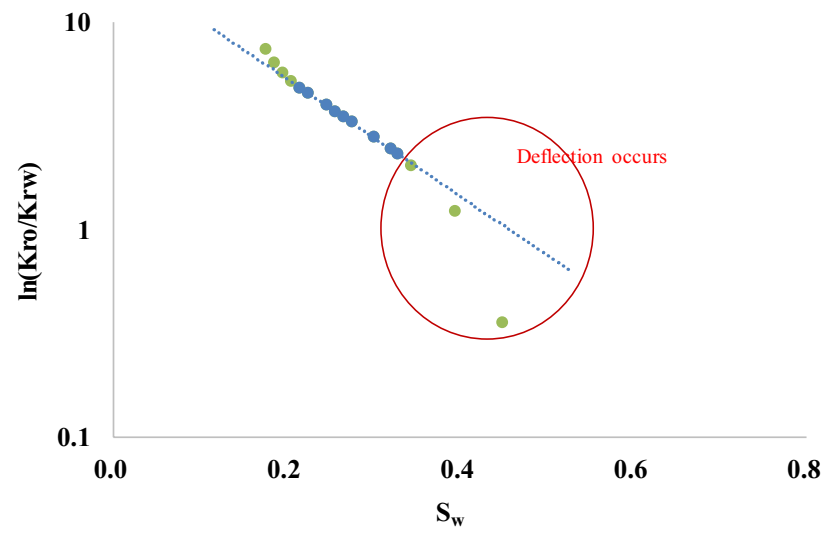

Fig. 1 Traditional water flooding characteristic curve method would deflect in the high water cut stage

\section{Establishment of water flooding characteristic curve for low-amplitude reservoir with strong bottom water}

\section{Derivation of water flooding characteristic curve for low-amplitude reservoir with strong bottom water}

According to Buckley-Leverett, water flooding front advancing equation, the functional relationship of $\overline{S_{w}}$ and $S_{w e}$ is as follows (Yuanqian and Cunyou 2014; Can and Kabir 2014):

$S_{w e}=\left(\frac{1}{1+k} \overline{S_{w}}+\frac{k}{1+k} S_{w i}\right)\left[1+\left(\frac{\overline{S_{w}}-S_{w i}}{m}\right)^{-1 / k}\right]^{-1}$

By deriving the two ends of formula (1):

$\frac{d S_{w e}}{d \overline{S_{w}}}=-\frac{1}{m k}\left[\frac{\frac{1}{1+k} \overline{S_{w}}+\frac{k}{1+k} S_{w i}}{1+\left(\frac{\overline{S_{w}}-S_{w i}}{m}\right)^{-1 / k}}-\overline{S_{w}}\right] \frac{\left(\frac{\overline{S_{w}}-S_{w i}}{m}\right)^{1 / k-1}}{1+\left(\frac{\overline{S_{w}}-S_{w i}}{m}\right)^{-1 / k}}$

Replace (1) with (2):

$\frac{d S_{w e}}{d \overline{S_{w}}}=-\frac{1}{m k}\left(S_{w e}-\overline{S_{w}}\right) \frac{\left(\frac{\overline{S_{w}}-S_{w i}}{m}\right)^{1 / k-1}}{1+\left(\frac{\overline{S_{w}}-S_{w i}}{m}\right)^{1 / k}}$

From the Welge equation, it can be concluded that:

$\frac{d f_{o e}}{d S_{w e}}=\frac{d f_{o e}}{d \overline{S_{w}}} \frac{d \overline{S_{w}}}{d S_{w e}}=\frac{f_{o e}}{S_{w e}-\overline{S_{w}}}$

By substituting (3) into (4): $\frac{d f_{o e}}{d \overline{S_{w}}}=-\frac{1}{m k} \frac{\left(\frac{\overline{S_{w}}-S_{w i}}{m}\right)^{1 / k-1}}{1+\left(\frac{\overline{S_{w}}-S_{w i}}{m}\right)^{1 / k}} f_{o e}$

Solve the above differential equation:

$f_{o e}=C_{1} /\left[1+\left(\frac{\overline{S_{w}}-S_{w i}}{m}\right)^{1 / k}\right]$

Then (6) the initial conditions are satisfied $\overline{S_{w}}=S_{w i}$, $f_{o e}=1$ (Replace $\overline{S_{w}}=S_{w i}$ into (1). The initial conditions can be determined $\overline{S_{w}}=S_{w i}$, then $\left.f_{o e}=1\right), C_{1}=1$, substitution it into (6):

$f_{o e}=1 /\left[1+\left(\frac{\overline{S_{w}}-S_{w i}}{m}\right)^{1 / k}\right]$

then

$\left(1-f_{o e}\right) / f_{o e}=\left(\frac{\overline{S_{w}}-S_{w i}}{m}\right)^{1 / k}$

From the definition,

$\left(1-f_{o e}\right) / f_{o e}=Q_{w} / Q_{o}$

$Q_{w}=d W_{p} / d t$

$Q_{o}=d N_{p} / d t$

Under the condition that the formation pressure is maintained by water injection and the reservoir is relatively homogeneous, it can be seen from the material balance equation that:

$\overline{S_{w}}=\frac{N_{p}\left(1-S_{w i}\right)}{N}+S_{w i}$

Combining (9) (10) (11) (12) with (8), we can get:

$d W_{p} / d N_{p}=\left[\left(1-S_{w i}\right) \frac{N_{p}}{m N}\right]^{1 / k}$

(13) When the initial conditions are satisfied $W_{p}=0$, $N_{p}=N_{p 0}$. By solving the above differential equations, we can obtain:

$\ln N_{p}=A+B \ln \left(W_{p}+C\right)$

where 
$\mathrm{A}=\frac{1}{1+k} \ln \left[\frac{1}{1+k}\left(\frac{m N}{1-S_{w i}}\right)^{1 / k}\right]$

$\mathrm{B}=\frac{1}{1+k}$

$\mathrm{C}=\frac{1}{1+k}\left(\frac{1-S_{w i}}{m N}\right)^{1 / k} N_{p 0}^{1+1 / k}$

There is no water-free oil recovery period in lowamplitude structural reservoir with strong bottom water, so $N_{p 0}=0, \mathrm{C}=0$, from (14)

$\ln \frac{W_{p}}{N_{p}}=a+b \ln N_{p}$

where $b=k ; a=\ln \left[\frac{1}{1+k}\left(\frac{m N}{1-S_{w i}}\right)^{1 / k}\right]$

According to the partial flow formula:

$f_{w}=1-f_{o e}=1 /\left[1+K_{r o} /\left(\mu_{r} K_{r w}\right)\right]$

The oil-water relative permeability ratio formula is:

$K_{r o} / K_{r w}=\mu_{r} /\left[\left(\overline{S_{w}}-S_{w i}\right) / m\right]^{1 / k}$

where

$f_{o e}, f_{w}$ - They are oil content and water content at the outlet, $f$;

$k$-Constant;

$K_{r o}, K_{r w}$-They are relative permeability of oil and water, dimensionless;

$L_{p}$-Cumulative liquid production, $10^{4} \mathrm{~m}^{3}$;

$m$-Constant coefficient;

$N, N_{p}$ - They are geological reserves and cumulative oil production, $10^{4} \mathrm{~m}^{3}$;

$Q_{L}, Q_{O}, Q_{W}$ - They are liquid production, oil production, and water production, $\mathrm{m}^{3} / d$;

$\overline{S_{w}}, S_{w i}$-They are average water saturation and irreducible water saturation, $f$;

$S_{w e}$-Water saturation at outlet, $f$

$W_{p}$-Cumulative water production, $10^{4} \mathrm{~m}^{3}$;

$\mu_{r}$-Oil-water viscosity ratio, dimensionless.

Substitute the actual relative permeability curve (see Table 2 and Fig. 2) into Formula 17. The relationship between $\frac{k_{r o}}{k_{r w}}$ and $S_{w}$ is obtained. The correlation coefficient of $\frac{k_{r o}}{k_{r w}}$ and $S_{w}$ has reached $95.92 \%$ (Fig. 3). The higher the water content, the better the fitting degree. It is suitable for lowamplitude reservoirs with strong bottom water.

Through the formula derivation in this section, the relationship between $\frac{k_{r o}}{k_{r w}}$ and $S_{w}$ is obtained. The correlation coefficient of $\frac{k_{r o}}{k_{r w}}$ and $S_{w}$ has reached $95.92 \%$. The water flooding
Table 2 Relative permeability under different water saturation

\begin{tabular}{lll}
\hline $\begin{array}{l}\text { water saturation } \\
(\mathrm{Sw})\end{array}$ & $\begin{array}{l}\text { Relative permeability of } \\
\text { water phase }(\mathrm{Krw})\end{array}$ & $\begin{array}{l}\text { Relative permeabil- } \\
\text { ity of oil phase (Kro) }\end{array}$ \\
\hline 0.12 & 0.00 & 0.93 \\
0.18 & 0.00 & 0.76 \\
0.18 & 0.00 & 0.73 \\
0.20 & 0.00 & 0.70 \\
0.21 & 0.00 & 0.67 \\
0.22 & 0.00 & 0.64 \\
0.23 & 0.01 & 0.61 \\
0.25 & 0.01 & 0.55 \\
0.26 & 0.01 & 0.52 \\
0.27 & 0.01 & 0.50 \\
0.28 & 0.02 & 0.47 \\
0.30 & 0.02 & 0.41 \\
0.32 & 0.03 & 0.36 \\
0.33 & 0.03 & 0.35 \\
0.34 & 0.04 & 0.31 \\
0.39 & 0.06 & 0.22 \\
0.45 & 0.09 & 0.13 \\
0.51 & 0.13 & 0.07 \\
0.53 & 0.15 & 0.05 \\
0.58 & 0.19 & 0.02 \\
0.60 & 0.21 & 0.01 \\
\hline
\end{tabular}

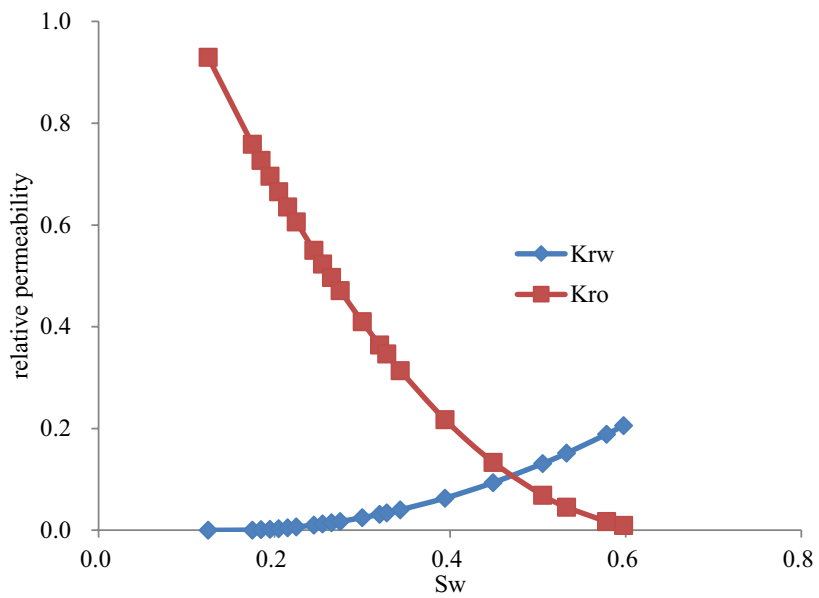

Fig. 2 Oil-water relative permeability of oilfield

characteristic curve suitable for a low-amplitude reservoir with strong bottom water is obtained.

\section{Using new water flooding characteristic curve to predict cumulative oil production $N_{P}$}

From Eq. (15), we can get the following results: 


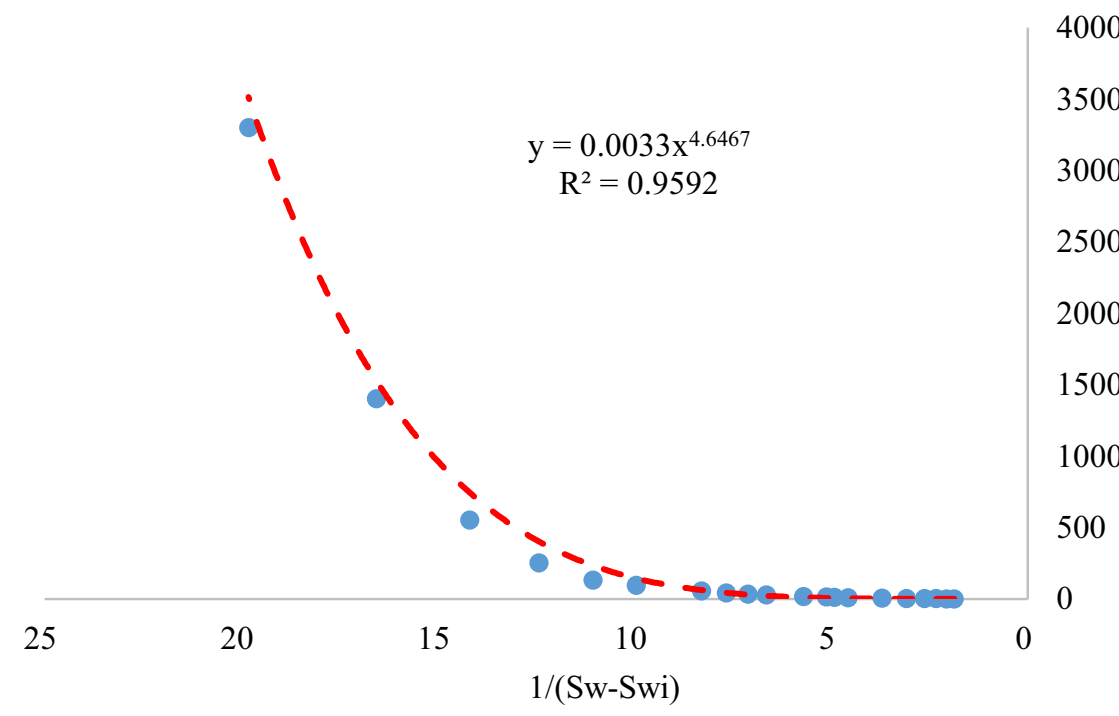

$\ln W_{p}=a+(b+1) \ln N_{p}$

The derivative of Eq. (18) to $N_{p}$ is obtained:

$\frac{1}{W_{p}} \frac{d W_{p}}{d N_{p}}=(b+1) \frac{1}{N_{p}}$

By WOR $=\frac{d W_{p}}{d N_{p}}$ :

$W_{p}=\frac{N_{p} W O R}{b+1}$

Substituting (20) into (18) yields:

$N_{p}=e^{\frac{\ln \frac{W O R}{b+1}-a}{b}}$

Through (21), recoverable reserves under a given water-oil ratio (which can be converted into water content) can be obtained.

This section uses the water flooding characteristic curve in Sect. 3.1 to derive the formula for calculating cumulative oil production $N_{p}$.

\section{Prediction of future water cut based on relative permeability}

From the yield equation (Zhaojie et al. 2013):

$$
\begin{aligned}
& Q_{o}=\frac{0.543 K K_{r o} h\left(P_{e}-P_{w f}\right)}{\mu_{o} B_{o}\left(\ln \frac{r_{e}}{r_{w}}+S\right)} \\
& Q_{w}=\frac{0.543 K K_{r w} h\left(P_{e}-P_{w f}\right)}{\mu_{w} B_{w}\left(\ln \frac{r_{e}}{r_{w}}+S\right)}
\end{aligned}
$$

4000

3500

3000

2500

2000

1500

000

500

(22) and (23), the:

$\frac{Q_{w}}{Q_{o}}=\frac{\mu_{o} B_{o} K_{r w}}{\mu_{w} B_{w} K_{r o}}$

(17) By substituting (24), the:

$\frac{Q_{w}}{Q_{o}}=\frac{B_{o}}{B_{w}}\left[\left(\overline{S_{w}}-S_{w i}\right) / m\right]^{1 / k}$

$N_{o}=100 A h \emptyset\left(1-S_{w i}\right) / B_{o}$

$N_{o r}=100 A h \emptyset\left(1-\overline{S_{w}}\right) / B_{o}$

From (26) and (27), the:

$\overline{S_{w}}=\left(1-S_{w i}\right) R_{o}+S_{w i}$

By substituting (28) into (25), the:

$\frac{Q_{w}}{Q_{o}}=\frac{B_{o}}{B_{w}}\left[\left(1-S_{w i}\right) R_{o} / m\right]^{1 / k}$

$f_{w}=\frac{Q_{w}}{Q_{o}+Q_{w}}=\frac{1}{\frac{Q_{o}}{Q_{w}}+1}=\frac{1}{\frac{1}{\frac{Q_{w}}{Q_{o}}}+1}$

By substituting (29) into (30), the:

$f_{w}=\frac{1}{\frac{1}{\frac{B_{o}}{B_{w}}\left[\left(1-S_{w i}\right) R_{o} / m\right]^{1 / k}}+1}$

According to formula (31), the future water cut under constant liquid volume can be obtained.

where 
$K$-Effective permeability of reservoir, $\mathrm{mD}$.

$\mu_{o}, \mu_{W}$-They are the viscosity of oil and the viscosity of water, $\mathrm{mPa} \cdot \mathrm{s}$.

$a, b$-Coefficient, $f$.

$B_{o}, B_{W}$-They are the volume coefficient of oil and the volume coefficient of water, $f$

$R_{o}$-Oil recovery, $f$

$A$-Reservoir cross section, $m^{2}$.

$h$-Valid thickness, $m$

$\emptyset$-Porosity, $f$

According to the relative permeability productivity formula, this section deduces the formula for calculating water cut when the cumulative oil production $N_{p}$ is known (Sect. 3.2).

\section{Case analysis}

The geological reserve of a strong bottom water sandstone reservoir is $2000 \times 10^{4} \mathrm{~m}^{3}$; the adequate thickness is $6 \mathrm{~m}$, the viscosity of crude oil is $50 \mathrm{mPa} \cdot \mathrm{s}$, the viscosity of water is $0.51 \mathrm{mPa} \cdot \mathrm{s}$, the density of oil is $0.923 \mathrm{~g} / \mathrm{cm}^{3}$, and the volume coefficient of oil is 1.13. Take A2H well in this oilfield as an example (see Table 3). According to Eq. (15), there is an excellent linear relationship between well $\ln \frac{W_{p}}{N_{p}}$ and $\ln N_{p}$ (Fig. 4). The corresponding a and b values can be obtained, and the water content calculated by the formula (31) is compared with the actual water content (Fig. 5). The calculated cumulative oil production is in good agreement with the actual cumulative oil production (Fig. 6). In this way, the recovery degree of a single well under different water cuts can be obtained.

The recoverable reserves under the given water-oil ratio (which can be converted into water content) are obtained.

Figure 4 shows $a=-21.175, b=1.8649$. It can be concluded from Eq. 15:

$\ln \frac{W_{p}}{N_{p}}=-21.175+1.8649 \ln N_{p}$

By $W_{p}+N_{p}=L_{P}$, Eq. 32 shows that:

$\ln \frac{L_{P}-N_{p}}{N_{p}}=-21.175+1.8649 \ln N_{p}$

Through Eq. 33, under the condition of constant liquid production (see Table 3 . The actual production data from $2021 / 3,48405 t$ ), in future, the accumulated liquid production $L_{p}$ at any time in future can be obtained; thus, the accumulated oil production $N_{p}$ at any time in future can be obtained. Through the accumulated oil production $N_{p}$, the monthly oil production can be obtained, and the corresponding water content can be obtained. That is to say, through Eq. 33, knowing $L_{P}$ and finding $N_{p}$, we can get the output of different water content at any time in future under constant liquid quantity.

According to the comparison between the actual data and the calculated data, in $2021 / 3$, the actual water cut is $97.29 \%$, the water cut predicted by the formula is $97.27 \%$, the actual cumulative oil production is $31.19 \times 10^{4} \mathrm{t}$, and the predicted cumulative oil production is $31.31 \times 10^{4} \mathrm{t}$. The predicted value is consistent with the actual value.

\section{Conclusions}

In this study, the derivation process of the conventional water flooding characteristic curve is studied. At the same time, according to the Buckley-Leverett water flooding front advancing equation, combined with the characteristics of strong bottom water and low-amplitude structural reservoir without a water-free oil recovery period, the water flooding characteristic curve is modified:

(1)The conventional water flooding characteristic curve method considers that the relative permeability ratio of oil-water two-phase is expressed as $\frac{k_{r o}}{k_{r w}}=c e^{-d \cdot S_{w o}}$. Through the actual data, it is found that the relationship between $\ln \left(\frac{k_{r o}}{k_{r w}}\right)$ and $S_{w}$ is only a straight line in a period, and there is a downward tilt in the later period.

(2) During the derivation of the conventional water flooding characteristic curve method, $\overline{S_{w}} \approx S_{w e}+\frac{1}{m f_{w}}$. It is assumed that after the oil field enters the high water cut stage ( $\left.f_{w}>80 \%\right), \overline{S_{w}} \approx S_{w e}$. In other words, the water saturation at the high water cut the average saturation of formation can replace stage outlet. But in the actual reservoir, $\overline{S_{w}} \neq S_{w e}$.

(3)After correction, the correlation coefficient between $\frac{k_{r o}}{k_{r w}}$ and $S_{w}$ is $95.92 \%$.

(4)According to the comparison between the actual data and the calculated data, in $2021 / 3$, the actual water cut is $97.29 \%$, the water cut predicted by the formula is $97.27 \%$, the actual cumulative oil production is $31.19 \times 10^{4} \mathrm{t}$, and the predicted cumulative oil production is $31.31 \times 10^{4} \mathrm{t}$. The predicted value is consistent with the actual value.

(5)The existing water flooding characteristic curve is corrected, and the improved water flooding characteristic curve in the high water cut period of low-amplitude structural reservoir with strong bottom water is obtained. The practical application is in line with the oilfield's actual situation, which provides a more reliable method for predicting the recoverability of low-amplitude structural reservoirs with strong bottom water and provides guidance for the subsequent decision-making of the oilfield. 
Table 3 Actual production data and forecast data of $\mathrm{A} 2 \mathrm{H}$

\begin{tabular}{|c|c|c|c|c|c|c|c|c|c|}
\hline Well Name & Date & $\begin{array}{l}\text { Monthly oil } \\
\text { production,t }\end{array}$ & $\begin{array}{l}\text { Monthly liquid } \\
\text { production,t }\end{array}$ & $\begin{array}{l}\text { Actual } \\
\text { water } \\
\text { cut, } \%\end{array}$ & $\begin{array}{l}\text { Actual cumulative } \\
\text { oil production, } 10^{4} \mathrm{t}\end{array}$ & $\begin{array}{l}\text { Calculate cumula- } \\
\text { tive oil production, } \\
10^{4} \mathrm{t}\end{array}$ & $\begin{array}{l}\text { Calculate } \\
\text { water } \\
\text { cut, } \%\end{array}$ & $\ln (\mathrm{Np})$ & $\ln (\mathrm{Wp} / \mathrm{Np})$ \\
\hline $\mathrm{A} 02 \mathrm{H}$ & $2011 / 4$ & 16,588 & 18,093 & 8.32 & 1.66 & 1.48 & 10.13 & 9.72 & -2.40 \\
\hline $\mathrm{A} 02 \mathrm{H}$ & $2011 / 5$ & 18,037 & 26,963 & 33.10 & 3.46 & 3.53 & 32.32 & 10.45 & -1.20 \\
\hline $\mathrm{A} 02 \mathrm{H}$ & $2011 / 6$ & 12,420 & 20,989 & 40.83 & 4.70 & 4.18 & 46.56 & 10.76 & -0.91 \\
\hline $\mathrm{A} 02 \mathrm{H}$ & $2011 / 7$ & 9343 & 17,447 & 46.45 & 5.64 & 4.69 & 55.41 & 10.94 & -0.73 \\
\hline $\mathrm{A} 02 \mathrm{H}$ & $2011 / 8$ & 7179 & 15,428 & 53.47 & 6.36 & 5.42 & 61.12 & 11.06 & -0.59 \\
\hline $\mathrm{A} 02 \mathrm{H}$ & $2011 / 9$ & 6176 & 14,863 & 58.45 & 6.97 & 6.01 & 65.35 & 11.15 & -0.46 \\
\hline $\mathrm{A} 02 \mathrm{H}$ & $2011 / 10$ & 5368 & 13,658 & 60.70 & 7.51 & 6.30 & 68.56 & 11.23 & -0.36 \\
\hline $\mathrm{A} 02 \mathrm{H}$ & $2011 / 11$ & 4837 & 13,798 & 64.94 & 7.99 & 6.91 & 71.14 & 11.29 & -0.27 \\
\hline $\mathrm{A} 02 \mathrm{H}$ & $2011 / 12$ & 4458 & 13,314 & 66.52 & 8.44 & 7.16 & 73.27 & 11.34 & -0.19 \\
\hline $\mathrm{A} 02 \mathrm{H}$ & $2012 / 1$ & 3823 & 11,981 & 68.09 & 8.82 & 7.43 & 74.94 & 11.39 & -0.12 \\
\hline $\mathrm{A} 02 \mathrm{H}$ & $2012 / 2$ & 2997 & 10,776 & 72.19 & 9.12 & 8.21 & 76.15 & 11.42 & -0.06 \\
\hline $\mathrm{A} 02 \mathrm{H}$ & $2012 / 3$ & 4187 & 15,332 & 72.69 & 9.54 & 8.31 & 77.71 & 11.47 & 0.02 \\
\hline $\mathrm{A} 02 \mathrm{H}$ & $2012 / 4$ & 2362 & 15,026 & 84.28 & 9.78 & 11.88 & 78.53 & 11.49 & 0.12 \\
\hline $\mathrm{A} 02 \mathrm{H}$ & $2012 / 5$ & 2824 & 15,631 & 81.93 & 10.06 & 10.91 & 79.46 & 11.52 & 0.20 \\
\hline $\mathrm{A} 02 \mathrm{H}$ & $2012 / 6$ & 2598 & 16,608 & 84.36 & 10.32 & 11.92 & 80.26 & 11.54 & 0.28 \\
\hline $\mathrm{A} 02 \mathrm{H}$ & $2012 / 7$ & 2012 & 16,905 & 88.10 & 10.52 & 14.00 & 80.86 & 11.56 & 0.37 \\
\hline $\mathrm{A} 02 \mathrm{H}$ & $2012 / 8$ & 1078 & 8061 & 86.63 & 10.63 & 13.08 & 81.16 & 11.57 & 0.40 \\
\hline $\mathrm{A} 02 \mathrm{H}$ & $2012 / 9$ & 1705 & 9714 & 82.45 & 10.80 & 11.11 & 81.64 & 11.59 & 0.43 \\
\hline $\mathrm{A} 02 \mathrm{H}$ & $2012 / 10$ & 3220 & 17,620 & 81.73 & 11.12 & 10.83 & 82.49 & 11.62 & 0.49 \\
\hline $\mathrm{A} 02 \mathrm{H}$ & $2012 / 11$ & 5219 & 28,467 & 81.67 & 11.64 & 10.81 & 83.75 & 11.67 & 0.56 \\
\hline $\mathrm{A} 02 \mathrm{H}$ & $2012 / 12$ & 4117 & 27,302 & 84.92 & 12.06 & 12.18 & 84.65 & 11.70 & 0.63 \\
\hline $\mathrm{A} 02 \mathrm{H}$ & 2013/1 & 3851 & 25,323 & 84.79 & 12.44 & 12.12 & 85.44 & 11.73 & 0.69 \\
\hline $\mathrm{A} 02 \mathrm{H}$ & $2013 / 2$ & 4528 & 29,124 & 84.45 & 12.89 & 11.96 & 86.29 & 11.77 & 0.75 \\
\hline $\mathrm{A} 02 \mathrm{H}$ & $2013 / 3$ & 3695 & 27,052 & 86.34 & 13.26 & 12.92 & 86.93 & 11.80 & 0.81 \\
\hline $\mathrm{A} 02 \mathrm{H}$ & $2013 / 4$ & 3258 & 22,259 & 85.36 & 13.59 & 12.40 & 87.46 & 11.82 & 0.84 \\
\hline $\mathrm{A} 02 \mathrm{H}$ & $2013 / 5$ & 3168 & 21,578 & 85.32 & 13.91 & 12.38 & 87.95 & 11.84 & 0.88 \\
\hline $\mathrm{A} 02 \mathrm{H}$ & $2013 / 6$ & 2607 & 17,912 & 85.45 & 14.17 & 12.44 & 88.33 & 11.86 & 0.90 \\
\hline $\mathrm{A} 02 \mathrm{H}$ & $2013 / 7$ & 3767 & 30,743 & 87.75 & 14.54 & 13.77 & 88.85 & 11.89 & 0.95 \\
\hline $\mathrm{A} 02 \mathrm{H}$ & $2013 / 8$ & 3085 & 31,954 & 90.35 & 14.85 & 15.78 & 89.25 & 11.91 & 1.00 \\
\hline $\mathrm{A} 02 \mathrm{H}$ & $2013 / 9$ & 3228 & 34,880 & 90.75 & 15.17 & 16.16 & 89.65 & 11.93 & 1.06 \\
\hline $\mathrm{A} 02 \mathrm{H}$ & $2013 / 10$ & 2904 & 34,393 & 91.56 & 15.46 & 17.01 & 89.99 & 11.95 & 1.11 \\
\hline $\mathrm{A} 02 \mathrm{H}$ & $2013 / 11$ & 2659 & 35,117 & 92.43 & 15.73 & 18.07 & 90.29 & 11.97 & 1.16 \\
\hline $\mathrm{A} 02 \mathrm{H}$ & $2013 / 12$ & 2519 & 34,035 & 92.60 & 15.98 & 18.30 & 90.56 & 11.98 & 1.20 \\
\hline $\mathrm{A} 02 \mathrm{H}$ & 2014/1 & 2373 & 32,743 & 92.75 & 16.22 & 18.51 & 90.80 & 12.00 & 1.24 \\
\hline $\mathrm{A} 02 \mathrm{H}$ & $2014 / 2$ & 2387 & 34,185 & 93.02 & 16.46 & 18.90 & 91.04 & 12.01 & 1.28 \\
\hline $\mathrm{A} 02 \mathrm{H}$ & $2014 / 3$ & 2263 & 33,175 & 93.18 & 16.68 & 19.14 & 91.25 & 12.02 & 1.32 \\
\hline $\mathrm{A} 02 \mathrm{H}$ & $2014 / 4$ & 2235 & 33,307 & 93.29 & 16.91 & 19.31 & 91.46 & 12.04 & 1.36 \\
\hline $\mathrm{A} 02 \mathrm{H}$ & $2014 / 5$ & 2109 & 32,103 & 93.43 & 17.12 & 19.54 & 91.65 & 12.05 & 1.39 \\
\hline $\mathrm{A} 02 \mathrm{H}$ & $2014 / 6$ & 2120 & 32,756 & 93.53 & 17.33 & 19.70 & 91.83 & 12.06 & 1.42 \\
\hline $\mathrm{A} 02 \mathrm{H}$ & $2014 / 7$ & 2211 & 33,603 & 93.42 & 17.55 & 19.52 & 92.02 & 12.08 & 1.45 \\
\hline $\mathrm{A} 02 \mathrm{H}$ & $2014 / 8$ & 2250 & 32,835 & 93.15 & 17.78 & 19.09 & 92.20 & 12.09 & 1.48 \\
\hline $\mathrm{A} 02 \mathrm{H}$ & $2014 / 9$ & 2375 & 33,514 & 92.91 & 18.01 & 18.74 & 92.38 & 12.10 & 1.50 \\
\hline $\mathrm{A} 02 \mathrm{H}$ & $2014 / 10$ & 1865 & 26,213 & 92.89 & 18.20 & 18.70 & 92.52 & 12.11 & 1.52 \\
\hline $\mathrm{A} 02 \mathrm{H}$ & $2014 / 11$ & 2373 & 33,321 & 92.88 & 18.44 & 18.69 & 92.70 & 12.12 & 1.55 \\
\hline $\mathrm{A} 02 \mathrm{H}$ & $2014 / 12$ & 2187 & 31,135 & 92.98 & 18.66 & 18.84 & 92.85 & 12.14 & 1.57 \\
\hline $\mathrm{A} 02 \mathrm{H}$ & 2015/1 & 2184 & 30,201 & 92.77 & 18.88 & 18.54 & 93.00 & 12.15 & 1.59 \\
\hline $\mathrm{A} 02 \mathrm{H}$ & $2015 / 2$ & 2510 & 34,496 & 92.72 & 19.13 & 18.47 & 93.17 & 12.16 & 1.61 \\
\hline $\mathrm{A} 02 \mathrm{H}$ & $2015 / 3$ & 2395 & 33,418 & 92.83 & 19.37 & 18.63 & 93.32 & 12.17 & 1.63 \\
\hline
\end{tabular}


Table 3 (continued)

\begin{tabular}{|c|c|c|c|c|c|c|c|c|c|}
\hline Well Name & Date & $\begin{array}{l}\text { Monthly oil } \\
\text { production,t }\end{array}$ & $\begin{array}{l}\text { Monthly liquid } \\
\text { production,t }\end{array}$ & $\begin{array}{l}\text { Actual } \\
\text { water } \\
\text { cut, } \%\end{array}$ & $\begin{array}{l}\text { Actual cumulative } \\
\text { oil production, } 10^{4} \mathrm{t}\end{array}$ & $\begin{array}{l}\text { Calculate cumula- } \\
\text { tive oil production, } \\
10^{4} \mathrm{t}\end{array}$ & $\begin{array}{l}\text { Calculate } \\
\text { water } \\
\text { cut, } \%\end{array}$ & $\ln (\mathrm{Np})$ & $\ln (\mathrm{Wp} / \mathrm{Np})$ \\
\hline $\mathrm{A} 02 \mathrm{H}$ & $2015 / 4$ & 2189 & 30,624 & 92.85 & 19.58 & 18.66 & 93.46 & 12.19 & 1.64 \\
\hline $\mathrm{A} 02 \mathrm{H}$ & $2015 / 5$ & 2003 & 28,444 & 92.96 & 19.78 & 18.81 & 93.58 & 12.20 & 1.66 \\
\hline $\mathrm{A} 02 \mathrm{H}$ & $2015 / 6$ & 1790 & 30,706 & 94.17 & 19.96 & 20.85 & 93.69 & 12.20 & 1.68 \\
\hline $\mathrm{A} 02 \mathrm{H}$ & $2015 / 7$ & 1757 & 31,085 & 94.35 & 20.14 & 21.20 & 93.79 & 12.21 & 1.70 \\
\hline $\mathrm{A} 02 \mathrm{H}$ & $2015 / 8$ & 1722 & 32,238 & 94.66 & 20.31 & 21.86 & 93.88 & 12.22 & 1.72 \\
\hline $\mathrm{A} 02 \mathrm{H}$ & $2015 / 9$ & 1412 & 26,498 & 94.67 & 20.45 & 21.88 & 93.96 & 12.23 & 1.73 \\
\hline $\mathrm{A} 02 \mathrm{H}$ & $2015 / 10$ & 1983 & 36,677 & 94.59 & 20.65 & 21.71 & 94.07 & 12.24 & 1.75 \\
\hline $\mathrm{A} 02 \mathrm{H}$ & $2015 / 11$ & 1960 & 36,492 & 94.63 & 20.85 & 21.79 & 94.17 & 12.25 & 1.77 \\
\hline $\mathrm{A} 02 \mathrm{H}$ & $2015 / 12$ & 1810 & 34,002 & 94.68 & 21.03 & 21.90 & 94.26 & 12.26 & 1.79 \\
\hline $\mathrm{A} 02 \mathrm{H}$ & 2016/1 & 1536 & 29,702 & 94.83 & 21.18 & 22.24 & 94.34 & 12.26 & 1.80 \\
\hline $\mathrm{A} 02 \mathrm{H}$ & $2016 / 2$ & 1837 & 34,716 & 94.71 & 21.37 & 21.97 & 94.43 & 12.27 & 1.82 \\
\hline $\mathrm{A} 02 \mathrm{H}$ & $2016 / 3$ & 1796 & 33,380 & 94.62 & 21.55 & 21.77 & 94.51 & 12.28 & 1.83 \\
\hline $\mathrm{A} 02 \mathrm{H}$ & $2016 / 4$ & 1898 & 35,189 & 94.61 & 21.73 & 21.74 & 94.60 & 12.29 & 1.85 \\
\hline $\mathrm{A} 02 \mathrm{H}$ & $2016 / 5$ & 1843 & 34,480 & 94.65 & 21.92 & 21.85 & 94.69 & 12.30 & 1.86 \\
\hline $\mathrm{A} 02 \mathrm{H}$ & $2016 / 6$ & 2551 & 47,232 & 94.60 & 22.17 & 21.73 & 94.80 & 12.31 & 1.88 \\
\hline $\mathrm{A} 02 \mathrm{H}$ & $2016 / 7$ & 2740 & 50,897 & 94.62 & 22.45 & 21.76 & 94.92 & 12.32 & 1.90 \\
\hline $\mathrm{A} 02 \mathrm{H}$ & $2016 / 8$ & 2710 & 50,432 & 94.63 & 22.72 & 21.79 & 95.03 & 12.33 & 1.92 \\
\hline $\mathrm{A} 02 \mathrm{H}$ & $2016 / 9$ & 4458 & 50,744 & 91.21 & 23.17 & 16.64 & 95.21 & 12.35 & 1.93 \\
\hline $\mathrm{A} 02 \mathrm{H}$ & $2016 / 10$ & 2983 & 29,821 & 90.00 & 23.46 & 15.47 & 95.32 & 12.37 & 1.94 \\
\hline $\mathrm{A} 02 \mathrm{H}$ & $2016 / 11$ & 2501 & 28,352 & 91.18 & 23.71 & 16.60 & 95.41 & 12.38 & 1.94 \\
\hline $\mathrm{A} 02 \mathrm{H}$ & $2016 / 12$ & 2823 & 36,060 & 92.17 & 24.00 & 17.74 & 95.51 & 12.39 & 1.95 \\
\hline $\mathrm{A} 02 \mathrm{H}$ & $2017 / 1$ & 2121 & 36,245 & 94.15 & 24.21 & 20.81 & 95.59 & 12.40 & 1.96 \\
\hline $\mathrm{A} 02 \mathrm{H}$ & $2017 / 2$ & 1987 & 42,620 & 95.34 & 24.41 & 23.51 & 95.65 & 12.41 & 1.98 \\
\hline $\mathrm{A} 02 \mathrm{H}$ & $2017 / 3$ & 2236 & 40,430 & 94.47 & 24.63 & 21.45 & 95.73 & 12.41 & 1.99 \\
\hline $\mathrm{A} 02 \mathrm{H}$ & $2017 / 4$ & 1445 & 24,067 & 94.00 & 24.77 & 20.52 & 95.77 & 12.42 & 2.00 \\
\hline $\mathrm{A} 02 \mathrm{H}$ & $2017 / 5$ & 1877 & 32,515 & 94.23 & 24.96 & 20.96 & 95.83 & 12.43 & 2.00 \\
\hline $\mathrm{A} 02 \mathrm{H}$ & $2017 / 6$ & 11 & 123 & 91.06 & 24.96 & 16.48 & 95.83 & 12.43 & 2.00 \\
\hline $\mathrm{A} 02 \mathrm{H}$ & $2017 / 7$ & 1564 & 26,567 & 94.11 & 25.12 & 20.74 & 95.88 & 12.43 & 2.01 \\
\hline $\mathrm{A} 02 \mathrm{H}$ & $2017 / 8$ & 1976 & 36,294 & 94.56 & 25.32 & 21.63 & 95.94 & 12.44 & 2.02 \\
\hline $\mathrm{A} 02 \mathrm{H}$ & $2017 / 9$ & 2055 & 38,231 & 94.62 & 25.52 & 21.78 & 96.00 & 12.45 & 2.03 \\
\hline $\mathrm{A} 02 \mathrm{H}$ & $2017 / 10$ & 1065 & 38,986 & 97.27 & 25.63 & 31.19 & 96.03 & 12.45 & 2.05 \\
\hline $\mathrm{A} 02 \mathrm{H}$ & $2017 / 11$ & 851 & 30,888 & 97.24 & 25.71 & 31.06 & 96.06 & 12.46 & 2.06 \\
\hline $\mathrm{A} 02 \mathrm{H}$ & $2017 / 12$ & 983 & 41,418 & 97.63 & 25.81 & 33.58 & 96.09 & 12.46 & 2.08 \\
\hline $\mathrm{A} 02 \mathrm{H}$ & 2018/1 & 1456 & 37,873 & 96.16 & 25.96 & 26.05 & 96.13 & 12.47 & 2.09 \\
\hline $\mathrm{A} 02 \mathrm{H}$ & $2018 / 2$ & 1748 & 36,298 & 95.18 & 26.13 & 23.11 & 96.18 & 12.47 & 2.10 \\
\hline $\mathrm{A} 02 \mathrm{H}$ & $2018 / 3$ & 1724 & 38,431 & 95.51 & 26.31 & 24.00 & 96.22 & 12.48 & 2.11 \\
\hline $\mathrm{A} 02 \mathrm{H}$ & $2018 / 4$ & 1833 & 42,816 & 95.72 & 26.49 & 24.61 & 96.27 & 12.49 & 2.12 \\
\hline $\mathrm{A} 02 \mathrm{H}$ & $2018 / 5$ & 1908 & 37,232 & 94.88 & 26.68 & 22.35 & 96.32 & 12.49 & 2.13 \\
\hline $\mathrm{A} 02 \mathrm{H}$ & $2018 / 6$ & 1917 & 39,779 & 95.18 & 26.87 & 23.10 & 96.37 & 12.50 & 2.14 \\
\hline $\mathrm{A} 02 \mathrm{H}$ & $2018 / 7$ & 386 & 7144 & 94.60 & 26.91 & 21.72 & 96.38 & 12.50 & 2.14 \\
\hline $\mathrm{A} 02 \mathrm{H}$ & $2018 / 8$ & 1913 & 42,194 & 95.47 & 27.10 & 23.87 & 96.43 & 12.51 & 2.15 \\
\hline $\mathrm{A} 02 \mathrm{H}$ & $2018 / 9$ & 2170 & 44,344 & 95.11 & 27.32 & 22.91 & 96.48 & 12.52 & 2.16 \\
\hline $\mathrm{A} 02 \mathrm{H}$ & $2018 / 10$ & 1800 & 35,468 & 94.93 & 27.50 & 22.47 & 96.53 & 12.52 & 2.17 \\
\hline $\mathrm{A} 02 \mathrm{H}$ & 2018/11 & 1808 & 34,676 & 94.79 & 27.68 & 22.14 & 96.57 & 12.53 & 2.17 \\
\hline $\mathrm{A} 02 \mathrm{H}$ & $2018 / 12$ & 1666 & 34,886 & 95.22 & 27.85 & 23.21 & 96.61 & 12.54 & 2.18 \\
\hline $\mathrm{A} 02 \mathrm{H}$ & $2019 / 1$ & 1583 & 34,753 & 95.44 & 28.00 & 23.81 & 96.65 & 12.54 & 2.19 \\
\hline $\mathrm{A} 02 \mathrm{H}$ & $2019 / 2$ & 1519 & 33,460 & 95.46 & 28.16 & 23.85 & 96.68 & 12.55 & 2.20 \\
\hline $\mathrm{A} 02 \mathrm{H}$ & $2019 / 3$ & 1568 & 33,865 & 95.37 & 28.31 & 23.60 & 96.71 & 12.55 & 2.20 \\
\hline
\end{tabular}


Table 3 (continued)

\begin{tabular}{|c|c|c|c|c|c|c|c|c|c|}
\hline Well Name & Date & $\begin{array}{l}\text { Monthly oil } \\
\text { production,t }\end{array}$ & $\begin{array}{l}\text { Monthly liquid } \\
\text { production,t }\end{array}$ & $\begin{array}{l}\text { Actual } \\
\text { water } \\
\text { cut, } \%\end{array}$ & $\begin{array}{l}\text { Actual cumulative } \\
\text { oil production, } 10^{4} \mathrm{t}\end{array}$ & $\begin{array}{l}\text { Calculate cumula- } \\
\text { tive oil production, } \\
10^{4} \mathrm{t}\end{array}$ & $\begin{array}{l}\text { Calculate } \\
\text { water } \\
\text { cut, } \%\end{array}$ & $\ln (\mathrm{Np})$ & $\ln (\mathrm{Wp} / \mathrm{Np})$ \\
\hline $\mathrm{A} 02 \mathrm{H}$ & $2019 / 4$ & 1696 & 33,735 & 94.97 & 28.48 & 22.58 & 96.75 & 12.56 & 2.21 \\
\hline $\mathrm{A} 02 \mathrm{H}$ & $2019 / 5$ & 1647 & 33,894 & 95.14 & 28.65 & 23.00 & 96.79 & 12.57 & 2.22 \\
\hline $\mathrm{A} 02 \mathrm{H}$ & $2019 / 6$ & 1760 & 33,897 & 94.81 & 28.82 & 22.19 & 96.82 & 12.57 & 2.22 \\
\hline $\mathrm{A} 02 \mathrm{H}$ & $2019 / 7$ & 1440 & 32,688 & 95.59 & 28.97 & 24.23 & 96.85 & 12.58 & 2.23 \\
\hline $\mathrm{A} 02 \mathrm{H}$ & $2019 / 8$ & 1358 & 32,516 & 95.82 & 29.10 & 24.93 & 96.88 & 12.58 & 2.24 \\
\hline $\mathrm{A} 02 \mathrm{H}$ & 2019/9 & 1211 & 35,604 & 96.60 & 29.22 & 27.80 & 96.91 & 12.59 & 2.24 \\
\hline $\mathrm{A} 02 \mathrm{H}$ & $2019 / 10$ & 1568 & 34,664 & 95.48 & 29.38 & 23.89 & 96.94 & 12.59 & 2.25 \\
\hline $\mathrm{A} 02 \mathrm{H}$ & 2019/11 & 1031 & 30,549 & 96.63 & 29.48 & 27.91 & 96.96 & 12.59 & 2.26 \\
\hline $\mathrm{A} 02 \mathrm{H}$ & 2019/12 & 817 & 27,549 & 97.03 & 29.57 & 29.88 & 96.97 & 12.60 & 2.27 \\
\hline $\mathrm{A} 02 \mathrm{H}$ & 2020/1 & 287 & 8714 & 96.71 & 29.59 & 28.27 & 96.98 & 12.60 & 2.27 \\
\hline $\mathrm{A} 02 \mathrm{H}$ & $2020 / 2$ & 374 & 8721 & 95.71 & 29.63 & 24.58 & 96.99 & 12.60 & 2.27 \\
\hline $\mathrm{A} 02 \mathrm{H}$ & $2020 / 3$ & 1333 & 45,609 & 97.08 & 29.76 & 30.11 & 97.01 & 12.60 & 2.28 \\
\hline $\mathrm{A} 02 \mathrm{H}$ & $2020 / 4$ & 1307 & 43,835 & 97.02 & 29.90 & 29.79 & 97.04 & 12.61 & 2.29 \\
\hline $\mathrm{A} 02 \mathrm{H}$ & $2020 / 5$ & 1091 & 37,235 & 97.07 & 30.00 & 30.07 & 97.06 & 12.61 & 2.30 \\
\hline $\mathrm{A} 02 \mathrm{H}$ & $2020 / 6$ & 765 & 24,575 & 96.89 & 30.08 & 29.13 & 97.07 & 12.61 & 2.30 \\
\hline $\mathrm{A} 02 \mathrm{H}$ & $2020 / 7$ & 1319 & 44,480 & 97.03 & 30.21 & 29.88 & 97.10 & 12.62 & 2.31 \\
\hline $\mathrm{A} 02 \mathrm{H}$ & $2020 / 8$ & 1464 & 42,795 & 96.58 & 30.36 & 27.71 & 97.12 & 12.62 & 2.32 \\
\hline $\mathrm{A} 02 \mathrm{H}$ & $2020 / 9$ & 1696 & 48,651 & 96.51 & 30.53 & 27.44 & 97.15 & 12.63 & 2.33 \\
\hline $\mathrm{A} 02 \mathrm{H}$ & $2020 / 10$ & 1740 & 46,277 & 96.24 & 30.70 & 26.36 & 97.18 & 12.63 & 2.34 \\
\hline $\mathrm{A} 02 \mathrm{H}$ & $2020 / 11$ & 1456 & 47,325 & 96.92 & 30.85 & 29.31 & 97.21 & 12.64 & 2.35 \\
\hline $\mathrm{A} 02 \mathrm{H}$ & $2020 / 12$ & 912 & 31,246 & 97.08 & 30.94 & 30.13 & 97.23 & 12.64 & 2.36 \\
\hline $\mathrm{A} 02 \mathrm{H}$ & $2021 / 1$ & 627 & 24,113 & 97.40 & 31.00 & 32.01 & 97.24 & 12.64 & 2.36 \\
\hline $\mathrm{A} 02 \mathrm{H}$ & $2021 / 2$ & 531 & 21,286 & 97.51 & 31.06 & 32.71 & 97.24 & 12.65 & 2.37 \\
\hline $\mathrm{A} 02 \mathrm{H}$ & $2021 / 3$ & 1313 & 48,405 & 97.29 & 31.19 & 31.31 & 97.27 & 12.65 & 2.38 \\
\hline
\end{tabular}

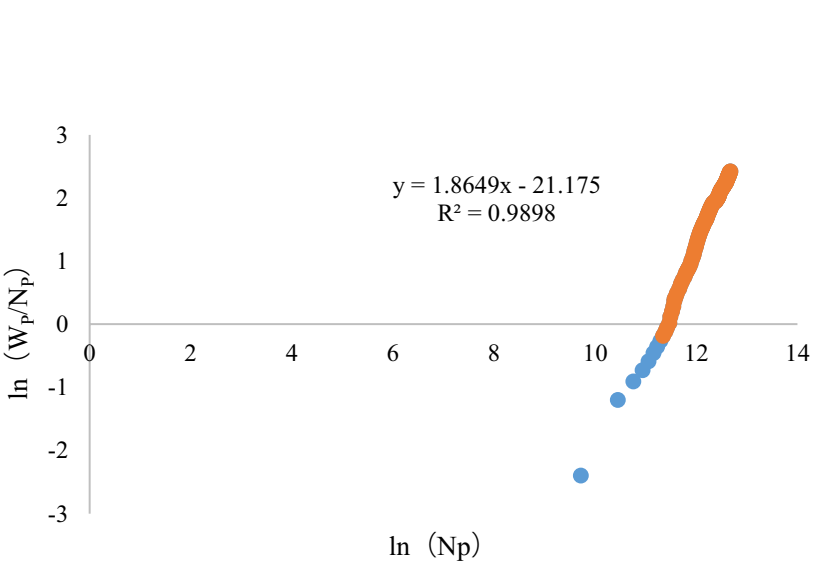

Fig. 4 Relation curve of $\ln \frac{W_{p}}{N_{p}}$ and $\ln N_{p}$ (the data of middle and high water cut stage were selected for linear regression)

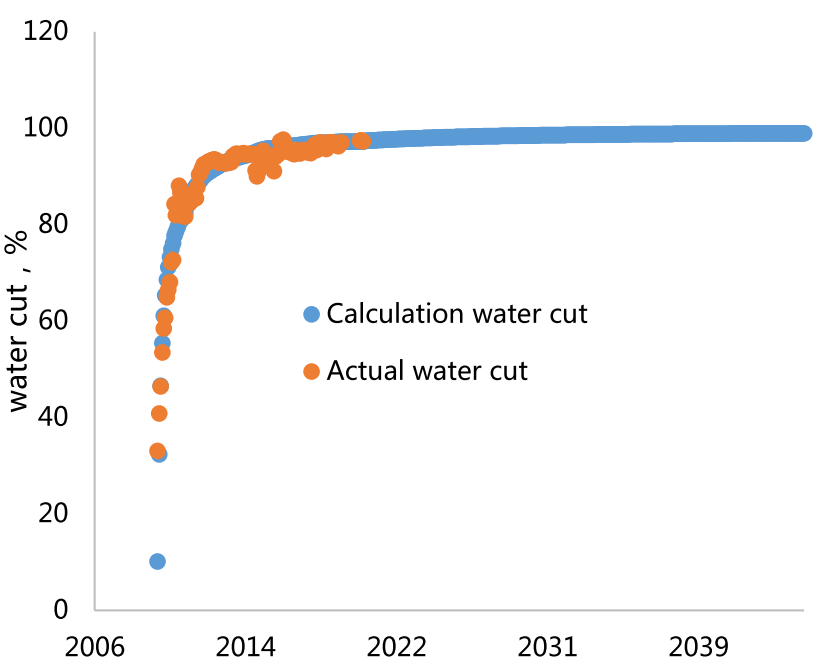

Fig. 5 Comparison between calculated water content and actual water content 


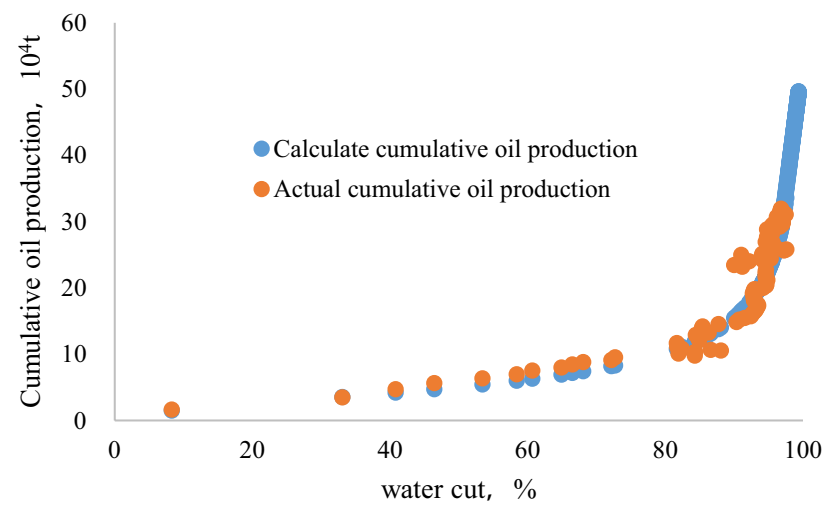

Fig. 6 Comparison between calculated cumulative oil production and actual cumulative oil production

Funding The project is supported by the National Science and Technology Major Project during the 13th Five-year Plan Period "Bohai Oilfield Efficient Development Demonstration Project" (Number 2016ZX05058). The funders had no role in study design, data collection, analysis, decision to publish, or manuscript preparation.

Open Access This article is licensed under a Creative Commons Attribution 4.0 International License, which permits use, sharing, adaptation, distribution and reproduction in any medium or format, as long as you give appropriate credit to the original author(s) and the source, provide a link to the Creative Commons licence, and indicate if changes were made. The images or other third party material in this article are included in the article's Creative Commons licence, unless indicated otherwise in a credit line to the material. If material is not included in the article's Creative Commons licence and your intended use is not permitted by statutory regulation or exceeds the permitted use, you will need to obtain permission directly from the copyright holder. To view a copy of this licence, visit http://creativecommons.org/licenses/by/4.0/.

\section{References}

Abass, H. H. and Bass D. M. (1988). The Critical Production Rate in Water-Coning Systems, SPE17311

Can B, Kabir CS (2014) Simple tools for forecasting waterflood performance. J Petrol Sci Eng 120:111-118

Changfu X, Hongxian L, Genbao Q et al (2011) Microcosmic mechanisms of water-oil displacement in conglomerate reservoirs in Karamay Oilfield. NW China Petrol Explor Developm 38(6):725-732

Chuanliang L.(2005). Principles of reservoir engineering. Beijing. Petroleum Industry Press. 419-451

Cunyou Z, Yuwen C, Guohui W et al (2011) Calculation on a reasonable production-injection well ratio in waterflooding oilfields[J]. Pet Explor Dev 38(2):211-215

Goda HM, Behrenbruch P, Maier HR (2007) Alternative modeling approaches for the estimation of irreducible water saturation: Australian hydrocarbon basins. J Petrol Sci Eng 57(1):60-69

Guo,B.,Milinard,J.E.and Lee,R.L. (1992). A Simple Approach to Optimization of Completion Interval in Oil/Water Coning Systems, SPE23994

Hanqiao J., Jun Y., Ruizhong J.(2006). The fundamental and practice of reservoir engineering. University of Petroleum Press, Dongying China
Hua W, Shaoxian B, Haiyan Z et al (2013) A new method suitable for water-oil displacement efficiency calculation in extra-high water cut period. Fault-Block Oil and Gas Field 20(2):201-203

Jackson M.D., Saunders J.H., Addiego-Guevara E.A. (2005). Development and Application of New Downhole Technology To Detect Water Encroachment Toward Intelligent wells. SPE97063

Jian H, Rongrong W, Zhizeng X et al (2013) Improvement of water displacement curve for water flooded oil reservoirs at ultrahigh water cut stage. J China Univ Petrol 37(6):72-75

Liu Y, Zou J, Meng X et al (2020) Experimental study on horizontalwell multi-thermal fluid stimulation process in offshore heavy oil reservoirs. J Petrol Explor Prod Technol 10:3057-3068. https:// doi.org/10.1007/s13202-020-00877-6

Muskat, M. and Wyckoff, R. D. (1935). An Approximate Theory of Water-coning in oil Production, Tans., AIME,144-161

Olabode O, Isehunwa S, Orodu O et al (2021) Optimizing productivity in oil rims: simulation studies on horizontal well placement under simultaneous oil and gas production. J Petrol Explor Prod Technol 11:385-397. https://doi.org/10.1007/s13202-020-01018-9

Qiaoyun L, Jiqun Z, Baorong D et al (2011) Grey decision-making theory in the optimization of strata series recombination programs of high water-cut oilfields. Pet Explor Dev 38(4):463-468

Qitai Y.(1998). Application of Zhang's water drive curve and its characteristics of oil-water seepage flow. Xinjiang Petroleum Geology. 19 (6) 507-511

Qitai Y.(1999). Characteristic of oil-water seepage flow for several important water drive curves. Acta petrologica Sinica. 20 (1) $56-60$

Qi-tai Y (1999) Oil and water flow characteristics of several important water drive curves. Acta Petrolei Sinica 20(1):56-60

Recham, R. (2000).Effects of Water Coning on the Performance of Vertical and Horizontal Wells-A Reservoir Simulation Study of Hassi R'mel Field, Algeria, SPE65506

Shaoxian B (2012) Study on relative permeability equation at ultrahigh water-cut stage. J Oil and Gas Technol 34(10):118-120

Shuhong J, Changbing T, Chengfang S et al (2011) New understanding on water-oil displacement efficiency in a high water-cut stage. Pet Explor Dev 38(3):338-345

Wang RR, Hou J, Li ZQ et al (2013) A new water displacement curve for the high water-cut stage. Petrol Sci Technol 31(13):1327-1334

Welge HJ (1952) A simplified method for computing oil recovery by gas or water drive. JPT 4(4):91-98

Wenjun G., Jun X.(2007). Theoretical study on common waterdrive characteristic curves. Acta Petrolei Sinica. 28 (3) 89-92

Wenjun G, Bingtao X, Qian W et al (2000) Using water drive curves for determination of piston displacement degree index. Xinjiang Petrol Geol 21(4):311-314

Yuanqian C.(1993). Derivation of a new type of water displacement curve and it's application. Acta Petrolei Sinica. 14(2):65-73

Yuanqian C.(1994). Simplification of hyperbolic decline and the intercept method of determining recoverable reserves. Natural Gas Industry. 14 (4) 32-37

Yuanqian C, Cunyou Z (2014) Model's typical curve and its application for forecasting production and recoverable reserves of oilfields. Acta Petrolei Sinica. 35(4):749-753

Yuanqian C, Dang L (2004) Modern petroleum reservoir engineering. Petroleum Industry Press, Beijing

Zhaojie S, Zhiping L, Fengpeng L et al (2013) Derivation of water flooding characteristic curve for high water-cut oilfields. Petrol explor devel 40(2):201-208 